\title{
ARTHUR PHILLIPS, O.B.E.,
}

1907-1991

\begin{abstract}
Although he did not become a member of the Ecclesiastical Law Society, having already retired as Chancellor of the Diocese of Winchester and as a Recorder of the Crown Court, Arthur was wholly supportive of the aims of the Society and enthusiastically greeted its formation. This is not surprising as he was a member of the Faculty Jurisdiction Commission which recommended that, while "No formal organisation analagous to the former Doctors' Commons should be created ... a welcome should be given to the proposals under consideration to enlarge the membership of the EJA and ELA to include other interested members of the legal profession". In fact that recommendation has been carried further so that the Society includes clergy as well as laity.
\end{abstract}

Arthur Phillips had a wide and interesting career in the law. He practised at the Bar after reading Greats at Oxford and then spent many years in Kenya as resident magistrate, crown counsel, solicitor general and later as judicial adviser. Back in England after the War he practised for a time on the Western Circuit and then, after being Reader in Law at the London School of Economics, he became in 1956 Professor of Law at Southampton University where he was responsible for setting up its very successful law faculty. Following his retirement from university life in 1971, he remained active in the law as a Recorder and Chancellor of Winchester as many of us remember him with particular affection. To the judicial office he brought clarity of thought, utter probity and also great compassion and understanding for those with whom he had to deal. His consistory court judgments are a model for us all. He was also editor of the Ecclesiastical Law volume of the fourth edition of Halsbury's Laws of England, which for many years has been the ecclesiastical law 'bible'.

Arthur was for many years a member of the Church Assembly and later the General Synod and served as a valued member of the Legal Advisory Commission of which he became Vice-Chairman, where his knowledge of the law and church life was of immense value.

But what many of us will recall with particular pleasure is the enjoyment we had simply by being in his company. A modest man, he also had a good sense of humour and showed interest in the lives and concerns of all those with whom he came into contact. He was also a great family man enjoying over fifty years of marriage to Kathleen, with whom he shared the joy of bringing up their four children. For many years a Lay Reader, everything he did in life was shot through by his Christian commitment. He will be sadly missed.

M.B.G. 